\title{
PENGEMBANGAN MODUL TEMATIK INTEGRATIF BERBASIS CHARACTER BUILDING
}

\author{
Siti Imma Nur Lailatul Farida ${ }^{1}$, Yulianti ${ }^{2}$ \\ Program Studi Pendidikan Guru SD, Universitas Kanjuruhan Malang, Indonesia \\ yulianti@unikama.ac.id ${ }^{2}$
}

\begin{abstract}
Abstrak
Proses pembelajaran di SD/MI telah menggunakan kurikulum 2013 namun belum didukung bahan ajar berupa printed text selain buku dari pemerintah dan LKS yang mengedepankan karakter. Penelitian ini bertujuan untuk menghasilkan modul tematik integratif dengan pendekatan kurikulum 2013 berbasis character building pada tema 9 subtema 3 .

Modul dikembangkan menggunakan Model Borg and Gall, dengan 10 langkah namun peneliti hanya menggunakan 5 langkah. Uji validasi dengan ahli materi, bahasa dan media. Subjek uji coba dalam penelitian ini adalah 1 orang guru SD dan 10 siswa SD kelas 4. Teknik pengumpulan data menggunakan angket. Teknik analisis data menggunakan data kuantitatif dan data kualitatif.

Hasil penelitian modul layak digunakan, berdasarkan penilaian ahli materi memperoleh skor $88,51 \%$, ahli bahasa $88,89 \%$, ahli media $94,44 \%$ dan peer reviewer $79,41 \%$. Modul praktis digunakan dengan perolehan skor $91,72 \%$, dan efektif digunakan dengan perolehan skor rata-rata $83,75 \%$. Diharapkan untuk pengguna modul tematik-integratif berbasis character building dapat dijadikan sebagai penunjang bahan ajar.
\end{abstract}

Kata kunci : Modul Tematik Integratif, Pendekatan Kurikulum 2013, Character Building

\begin{abstract}
The learning process in grade 4 using the 2013 curriculum has not been supported by teaching materials in the form of other printed texts from books and worksheets which prioritize characters. This study aims to develop an integrated thematic module with a 2013 curriculum approach based on the character of the building, and the feasibility of theme 9 sub-theme 3.

The module using the Model Borg and Gall learning design model, 10 steps but researcher using only 5 steps. Validation test with material, language and media experts. The trial subjects in this study were 1 elementary school teacher and 10 elementary school grade 4 students. Data writing techniques used questionnaires. Data analysis techniques use quantitative data and qualitative data.

The results showed that the module, based on assessment, scores $88.51 \%$, language experts 88.89\%, expert media $94.44 \%$ and $79.41 \%$ peer reviewers. General module with a score of $91.72 \%$, and can be used with an average score of $83.75 \%$. It is expected that userof thematicintegrative modules can support teaching materials.
\end{abstract}

Keywords: Integrative Thematic Module, Scientific, Character Building 


\section{PENDAHULUAN}

Pembelajaran tematik di sekolah dasar sudah berlangsung sejak dimulainya tahun ajaran 2007. Awal pelaksanaan pembelajaran tematik dilaksanakan di kelas I, II dan III pada jenjang sekolah dasar pada kurikulum KTSP. Seiring dengan berjalannya waktu, dengan perkembangan zaman dan teknologi, pelaksanaan pembelajaran tematik di sekolah dasar juga dilaksanakan di kelas IV sampai VI pada tahun 2013. Hal ini dilaksanakan sesuai dengan teori perkembangan kognitif, bahwa siswa SD masih belum bisa berpikir secara terpisah-pisah, tetapi mereka berpikir secara holistik dengan subjek yang konkret, sehingga untuk menghadapi hal tersebut maka diterapkanlah pembelajaran tematik ini. Pembelajaran tematik merupakan pembelajaran terpadu, dengan mengelola pembelajaran yang mengintegrasikan materi dari beberapa mata pelajaran dalam satu topik pembicaraan yang disebut tema (Prastowo, 2014). Berdasarkan uraian diatas dapat diartikan bahwa terdapat pengintegrasian beberapa mata pelajaran ke dalam satu tema dalam pembelajaran tematik ini.

Pelaksanaan pembelajaran di sekolah memerlukan perangkat pembelajaran agar dapat berlangsung sesuai dengan kompetensi yang diharapkan. Dalam pelaksanaan pembelajaran tematik diperlukan adanya persiapan guru dalam pembuatan RPP dan pengembangan silabus. Selain itu, guru juga dituntut untuk mampu menyusun bahan ajar yang inovatif, variatif, dan menarik bagi peserta didik sebagai salah satu upaya yang digunakan untuk mengurangi kejenuhan belajar pada siswa (Kadir, 2011).

Menurut Kadir (2011), bahan ajar tersebut dapat berupa bahan ajar cetak, misalnya lembar kerja siswa (LKS), handout, buku, modul, brosur, leaflet, wilchart, dan lain-lain, bahan ajar berbentuk audio visual misalnya film/video dan VCD, bahan ajar berbentuk audio misalnya kaset, radio, dan CD audio. Bahan ajar visual, misalnya foto, gambar, model/market, serta multimedia, misalnya CD interaktif, computer based learning dan internet. Dari berbagai jenis bahan ajar yang ada, salah satu yang sering digunakan di dalam proses pembelajaran adalah modul. Dikarenakan modul memuat petunjuk kegiatan belajar secara mandiri (self instructional) serta memberikan kesempatan kepada siswa untuk menguji diri sendiri melalui latihan yang disajikan dalam modul (Kadir, 2011).

Selain pentingnya modul dalam pembelajaran, pendidikan karakter juga merupakan suatu hal yang sangat dibutuhkan bagi peserta didik untuk saat ini. Kualitas moral dalam kehidupan manusia Indonesia dewasa ini, terutama di kalangan siswa, menuntut diselenggarakannya pendidikan karakter (Sudrajat, 2011).

Menurut Jannah (2012), pendidikan karakter dapat dimaknai sebagai pendidikan nilai, pendidikan moral, pendidikan watak, yang bertujuan mengembangkan peserta didik untuk memberikan keputusan baik-baik, memelihara apa yang baik, mewujudkan dan menebarkan kebaikan itu dalam kehidupan sehari hari dengan sepenuh hati (M.Arifin, 2012).

Berdasarkan uraian dalam latar belakang, maka penulis beranggapan bahwa perlu adanya bahan ajar yang dapat dijadikan sumber belajar dengan penekanan penanaman karakter yang berupa peduli lingkungan dan tanggung jawab bagi siswa di sekolah atau dirumah. Salah satu media pembelajaran yang 
dapat digunakan adalah modul mandiri, karena modul adalah satuan bahan ajar yang disusun secara sistematis dengan bahasa yang mudah dipahami oleh siswa sesuai tingkat pengetahuan dan usia siswa, agar siswa dapat belajar sendiri dengan bantuan atau bimbingan yang minimal dari pendidik.

\section{METODE PENELITIAN}

Penelitian ini termasuk jenis penelitian pengembangan atau yang sering dikenal dengan Research and Development (R\&D). Metode penelitian dalam pengembangan bahan ajar modul tematik integratif berbasis character building ini memanfaatkan langkah-langkah penelitian pengembangan Borg \& Gall dalam Hasyim.

Langkah-langkah pengembangan seperti diuraikan di bawah ini, yaitu (1) Research and Information collection, penelitian dan pengumpulan data, (2) Planning atau perencanaan, (3) Develop Preliminary form of Product atau pengembangan draf produk awal (4) Prelimilinary Field Testing atau melakukan uji coba lapangan awal, (5) Main Product Revision atau revisi hasil uji coba,(6) Main Field Testing atau uji lapangan untuk produk utama, (7) Operational Product Revision atau revisi produk (8) Operational Field Testing atau melakukan uji coba lapangan skala luas, (9) Final Product Revision atau revisi produk final, dan (10) Dissemination and Implementasi (Hasyim, 2016).

Pada penelitian pengembangan ini, peneliti hanya mengambil lima langkah dari kesepuluh langkah model yang ada pada model pangembangan Borg \& Gall dalam ini, diantaranya adalah:

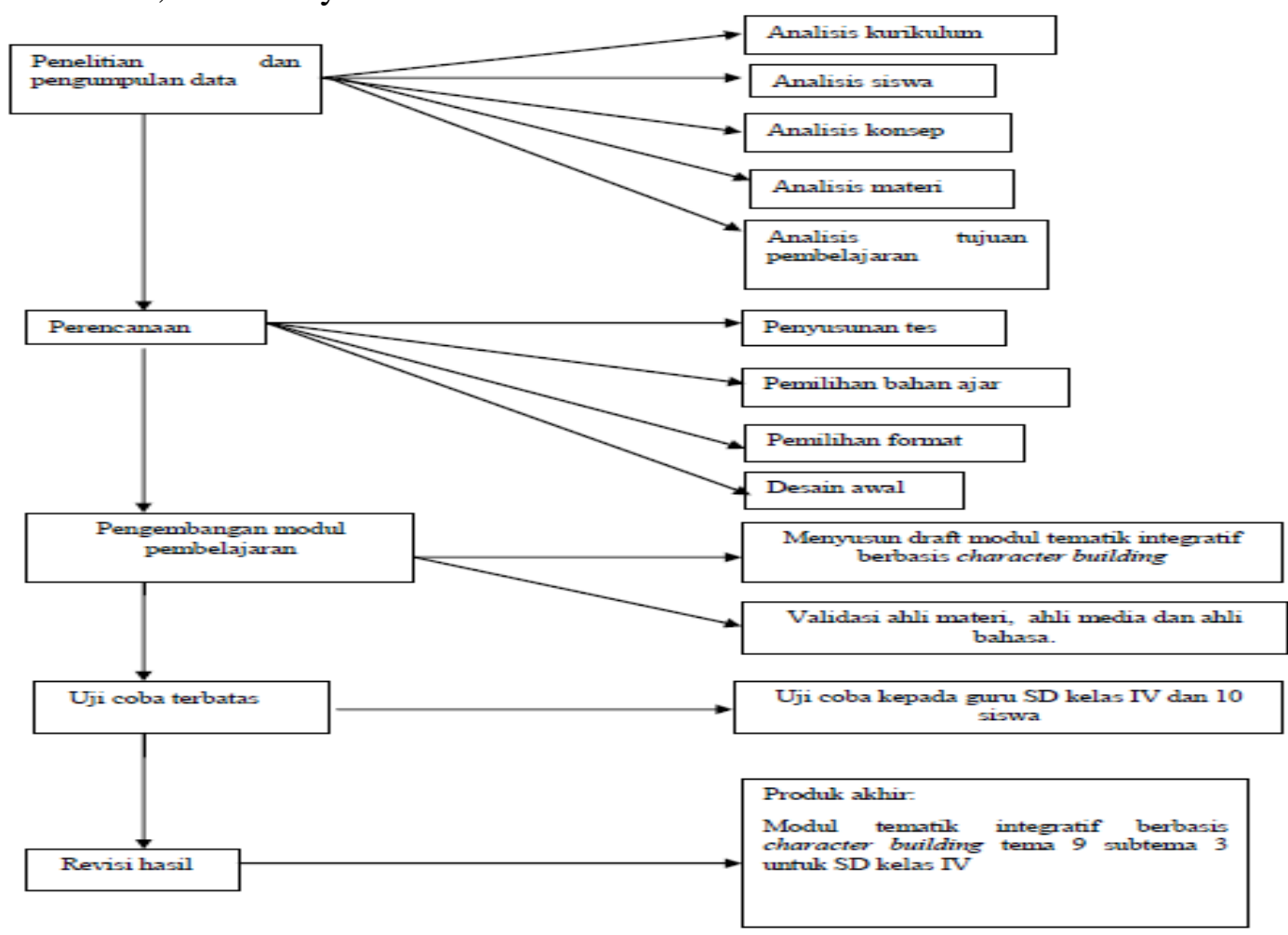

Bagan 1 Prosedur Pengembangan Modul Integratif berbasis Character Building (dimodifikasi dari Sugiyono 2010) 
Subjek uji coba dibagi dalam beberapa tahap.Pada tahap validasi uji kelayakan dilakukan oleh dua orang ahli materi dan tampilan modul, pada tahap validasi oleh pengguna dilakukan oleh 1 orang guru kelas IV SDN 03 Plaosan.Tahap selanjutnya pada uji coba lapangan terbatas dilakukan oleh 10 orang siswa kelas IV SDN 03 Plaosan. Instrumen pada penelitian ini terdiri dari angket yang diberikan kepada para validator, peer reviewed dan angket untuk 10 siswa. Teknik analisis data dalam penelitian ini menggunakan analisis data kuantitatif dan kualitatif.

\section{HASIL DAN PEMBAHASAN}

Hasil pengembangan bahan ajar modul pada penelitian ini, dijabarkan berikut ini. Pada tahap penelitian dan pengumpulan data terdapat analisis kurikulum, dalam langkah ini peneliti melakukan observasi partisipan dan wawancara terhadap guru kelas IV SDN Plaosan 03, dan wali murid kelas IV. Hal ini dilakukan untuk mengetahui permasalahan dasar yang dialami guru dan wali murid dalam proses pembelajaran yang menggunakan kurikulum 2013 khususnya pada tema 9 kayanya negeriku, subtema 3 pelestarian sumber daya alam di Indonesia. Dari observasi partisipan yang dilakukan oleh peneliti dalam proses pembelajaran menggunakan $\mathrm{K} 13$, belum ada bahan ajar berupa printed text lain selain buku dari pemerintah yang digunakan dalam kegiatan pembelajaran. Kegiatan pembelajaran hanya memanfaatkan buku teks dari pemerintah dan didampingi dengan penggunaan LKS, di sisi yang lain siswa membutuhkan bahan ajar yang dapat digunakan dalam kegiatan belajar di sekolah atau di rumah. Selain itu, persediaan buku dari pemerintah juga terbatas sehingga tidak semua siswa mendapatkan buku untuk belajar. Selain itu, kurangnya penanaman pendidikan karakter pada setiap pembelajaran, sehingga menyebabkan siswa kurang memahami arti dari pentingnya pendidikan karakter.

Pada prinsipnya, pengembangan pendidikan muatan karakter tidak dimasukkan sebagai pokok bahasan tetapi terintegrasi ke dalam mata pelajaran, pengembangan diri, pembiasaan, dan budaya sekolah. oleh karena itu, untuk proses pembelajaran di sekolah guru, perlu mengintegrasikan nilai-nilai muatan pendidikan karakter ke dalam kurikulum, yang salah satunya adalah bahan ajar berupa modul pembelajaran. Hal ini sesuai dengan pernyataan bahwa buku ajar ataupun modul dapat membantu siswa belajar mandiri (self intruction), tanpa bantuan guru (Sanjaya, 2010).

Hasil wawancara dengan seorang wali murid yang merasa terbebani dalam membantu putranya pada pembelajaran tematik, karena kurangnya bahan ajar lain bagi siswa di rumah. Sehingga siswa merasa kesulitan dalam mengikuti pembelajaran di sekolah serta tidak dapat mengerjakan tugas dan latihan yang terdapat pada buku teks tematik. Di dalam buku teks tematik dari pemerintah tidak terdapat banyak soal sebagai sarana berlatih menghadapi ulangan harian, pelatihan tengah semester dan pelatihan akhir semester, sehingga diharapkan dari adanya modul tematik integratif berbasis character building ini dapat membantu siswa belajar mandiri melalui latihan soal pada tes formatif yang ada pada modul.

Pada tahap analisis siswa, proses pembelajaran menunjukkan bahwa dalam tema 9 subtema 3 siswa terlihat kurang aktif, jika guru bertanya hanya 
beberapa siswa saja yang menjawab, oleh siswa yang sama. Hal tersebut menunjukkan pengetahuan siswa hanya dari apa yang disampaikan oleh guru, siswa tidak mencari sumber lain misalnya, membeli buku yang berkaitan dengan materi atau mencari di internet. Dalam proses pembelajaran siswa masih pasif, karena materi yang ada di buku belum semua ada di lingkungan sekitar siswa sehingga siswa mendengarkan penjelasan dari satu sumber saja, dan mengerjakan soal-soal yang diberikan oleh guru dengan keterbatasannya.Hal itu dikarenakan cara belajar siswa SD kelas 4 yang lebih tertarik pada bahan ajar yang disertai dengan ilustrasi atau gambar.

Analisis tugas berupa kompetensi yang akan dikembangkan dalam proses pembelajaran. Kegiatan ini ditujukan untuk mengidentifikasi kemampuan kognitif yang dimiliki oleh siswa yang akan dikembangkan dalam pembelajaran dengan materi pada tema 9 subtema 3. Analisis tugas dilakukan dengan cara mengidentifikasi materi utama yang perlu dianjurkan, mengumpulkan data, dan memilih materi yang relevan dan menyusunnya kembali secara sistematis. Analisis tugas darinilai-nilai peduli lingkungan dan tanggung jawab dilakukan agar modul tema 9 subtema 3 berbasis character building benar-benar dapat membantu siswa belajar secara mandiri, dikarenakan kurangnya latihan soal dalam buku teks siswa dari pemerintah, dan diharapkan dari adanya modul tematik integratif berbasis character building ini dapat menjadikan siswa berkarakter tanggung jawab dan peduli lingkungan setelah menggunakan modul tersebut.

Analisis konsep bertujuan untuk menentukan isi materi dalam modul tema 9 subtema 3 berbasis character building yang dikembangkan. Analisis konsep dibuat dalam peta konsep pembelajaran yang nantinya digunakan sebagai sarana pencapaian kompetensi tertentu dengan cara mengidentifikasi dan menyusun secara sistematis bagian-bagian utama materi pembelajaran. Hal ini dikarenakan dalam buku teks dari pemerintah, siswa masih merasa kebingungan dalam menentukan konsep dari materi yang dimuat dalam buku teks siswa tersebut.

Tahap analisis tujuan pembelajaran ini dilakukan untuk menentukan tujuan pembelajaran yang akan digunakan dalam perangkat pembelajaran yang akan dirancang oleh peneliti sesuai dengan Kompetensi Dasar dan Indikator yang akan dirumuskan dalam modul tematik integratif berbasis character building.

Tahap selanjutnya adalah perencanaan, meliputi penyusunan tes, pemilihan bahan ajar, pemilihan format dan desain awal. Peneliti akan menyusun instrumen yang akan digunakan untuk mengetahui kelayakan dan keefektifan modul yang akan dikembangkan dan instrumen yang akan digunakan untuk menilai keterampilan siswa dalam menggunakan modul yang dirancang oleh peneliti.

Langkah selanjutnya pemilihan bahan ajar didasarkan pada analisis yang dilakukan pada tahap pengumpulan data. Pemilihan bahan ajar juga disesuaikan dengan kebutuhan serta karakteristik peserta didik di SDN 03 Plaosan yang lebih tertarik kepada bahan ajar yang disertai dengan ilustrasi atau gambar dan latihan soal dalam setiap pembelajaran.

Pemilihan format dilakukan agar modul sesuai dengan kebutuhan peserta didik yang dapat digunakan dalam pembelajaran tematik. Penyajian format 
pembelajaran yang dipilih yaitu menarik, memudahkan siswa, dan dapat membantu siswa kelas IV untuk memahami nilai-nilai karakter tanggung jawab dan peduli lingkungan dalam pembelajaran tematik pada tema 9 subtema 3 .

Pada pembuatan desain awal, bertujuan untuk merancang draft awal modul tematik integratif dengan pendekatan kurikulum 2013 pada kelas IV berbasis character building yang akan dikembangkan oleh peneliti. Sebelum modul ini diuji cobakan di lapangan, maka pada tahap ini dihasilkan modul tematik integratif dengan pendekatan kurikulum 2013 pada kelas IV berbasis character building sebagai draft pertama (Maryani \& Ismaniati, n.d.)

Tahap ketiga adalah pengembangan modul pembelajaran yang meliputi penyusunan draft modul tematik berbasis character building dan validasi produk oleh para ahli. Kegiatan yang dilakukan pada tahap penyusunan draft modul ini antara lain diawali dengan pembuatan cover, kata pengantar, petunjuk penggunaan modul, daftarisi, kompetensi inti, kompetensi dasar, peta konsep pendidikan karakter, pemetaan indikator pembelajaran, materi, penugasan, umpan balik dan tindak lanjut, latihan soal, glosarium dan kunci jawaban tes formatif. Langkah selanjutnya adalah validasi dari ahli materi, ahli bahasa dan ahli media. Berikut merupakan hasil validasi dari para ahli:

Tabel 1 Hasil Validasi Ahli Materi

\begin{tabular}{clcc}
\hline No & \multicolumn{1}{c}{ Aspek } & Skor & Keterangan \\
\hline 1 & Kelayakan isi & $89,58 \%$ & Layak \\
\hline 2 & Kelayakan penyajian & $85 \%$ & Layak \\
\hline 3 & Penilaian kontekstual & $88,89 \%$ & Layak \\
\hline 4 & Penilaian character building & $91,67 \%$ & Sangat layak \\
\hline & Total keseluruhan & $88,51 \%$ & Layak \\
\hline
\end{tabular}

Dari 4 aspek yang berisi 37 butir pernyataan diperoleh skor keseluruhan sebesar $88,51 \%$ yang dikategorikan "Layak" yang berarti modul tematik integratif kelas 4 berbasis character building tidak perlu direvisi. Dengan demikian dapat dipahami bahwa modul tematik integratif kelas 4 berbasis character building yang telah dibuat oleh peneliti layak untuk diuji cobakan.Validator materi juga menyarankan sebaiknya peneliti mencamtumkan nama gambar pada setiap gambar yang ada, penambahan daftar pustaka dari internet, serta pemberian background pada peta konsep".

Tabel 2 Skor Ahli Bahasa

\begin{tabular}{llcc}
\hline No & Aspek & Skor & Keterangan \\
\hline 1. & Kelayakan bahasa & $88,89 \%$ & Layak \\
\hline
\end{tabular}

Dari tabel 2 diatas dapat diketahui bahwa skor yang didapat pada aspek kelayakan bahasa mendapat $88,89 \%$ yang dikategorikan "Layak" yang berarti modul tematik integratif kelas 4 berbasis character building tidak perlu direvisi. Validator bahasa juga menyarankan sebaiknya kalimat perintah dilengkapi pada setiap soal latihan atau kegiatan. 
Validator ahli media menyarakan perbaikan pada penulisan daftar pustaka modul dan sebaiknya di awal modul ditambahkan peta karakter yang muncul di setiap pembelajaran. Berikut hasil uji kelayakan ahli media:

\begin{tabular}{cccc}
\multicolumn{4}{c}{ Tabel 3 Skor Ahli Media } \\
\hline No & Aspek & Skor & Keterangan \\
\hline 1 & Kelayakan kegrafikaan & $94,44 \%$ & Sangat layak \\
\hline
\end{tabular}

Dari tabel 3 diatas dapat diketahui bahwa skor yang didapat pada aspek kelayakan ahli media atau kegrafikaan mendapat 94,44\% yang dikategorikan "Sangat Layak" yang berarti modul tematik integratif kelas 4 berbasis character building tidak perlu direvisi.

Tahap keempat adalah uji coba lapangan terbatas, diantaranya uji coba terbatas guru, uji coba terbatas siswa dan hasil tes kemampuan siswa dalam menyelesaikan soal. Pada uji coba terbatas yang ditujukan untuk guru SD kelas IV, peneliti memberikan modul beserta angket respon yang berisi 34 point pernyataan modul kepadaguru untuk dibaca selama 1 hari. Adapun hasil uji terbatas pada guru dapat dilihat pada tabel 4.

Tabel 4 Uji Coba Terbatas Guru

\begin{tabular}{llcl}
\hline No & Aspek & Skor & Keterangan \\
\hline 1. & Kelayakan isi & $79,41 \%$ & Layak
\end{tabular}

Dari tabel 4 diatas dapat diketahui bahwa skor yang didapat pada aspek kelayakan isi dari guru atau peer reviewer mendapat 79,41\% yang dikategorikan "Layak" yang berarti modul tematik integratif kelas 4 berbasis character building tidak perlu direvisi. Adapun data hasil uji coba terbatas pada siswa dapat dilihat pada tabel 5.

Tabel 5 Hasil Uji coba Lapangan Terbatas Siswa

\begin{tabular}{clcc}
\hline No & Indikator & Prosentase/ Aspek & Kategori \\
\hline 1. & Ketertarikan & 91 & Sangat Praktis \\
\hline 2. & Materi & 87,5 & Sangat Praktis \\
\hline 3. & Bahasa & 96,67 & Sangat Praktis \\
\hline \multicolumn{2}{r}{ Total keseluruhan } & 91,72 & Sangat Praktis \\
\hline
\end{tabular}

Dapat diketahui bahwa hasil uji lapangan terbatas terhadap modul tematik integratif kelas 4 berbasis character building dalam kategori“" sangat praktis” dengan rata-rata $91,72 \%$. Soal uji coba tes bertujuan untuk mengetahui kemampuan siswa dalam menyelesaikan soal tes. Adapun hasil tes kemampuan siswa dalam menyelesaikan soal disajikan dalam Tabel 6.

Tabel 6 Hasil Tes Kemampuan Siswa dalam Menyelesaikan Soal

\begin{tabular}{cccc}
\hline$\sum$ siswa & $\sum$ nilai tes & Rata-rata & Kriteria \\
\hline 10 & 837,5 & 83,75 & $>$ KKM \\
\hline
\end{tabular}


Berdasarkan Tabel 6 diperoleh rata-rata nilai tes 87. Dalam keterangan kriteria keefektifan pada BAB III, modul tematik integratif kelas 4 berbasis character building dikatakan "efektif" apabila memenuhi Kriteria Ketuntasan Minimal (KKM) yaitu 75 sesuai dengan yang telah ditentukan oleh SDN Plaosan 3 Kabupaten Malang. Setelah tahap validasi dan uji coba lapangan terbatas selesai dilakukan, maka modul direvisi berdasarkan hasil saran dari ahli materi, ahli bahasa, ahli media, respon guru kelas IV, dan respon peserta didik.

Penelitian dan Pengembangan modul tematik integratif berbasis character building ini didasarkan pada permasalahan yang ditemukan oleh peneliti pada tahap analisis, yaitu tidak adanya bahan ajar berupa printed text lain selain LKS dan buku dari pemerintah, serta kurangnya materi tentang pendidikan karakter tanggung jawab dan peduli lingkungan dalam setiap pembelajaran. Berdasarkan hasil analisis kurikulum kebutuhan, perlu dikembangkan suatu alternatif bahan ajar yang dapat digunakan sebagai pendamping siswa dalam kegiatan belajar di sekolah maupun di rumah. Salah satu alternatif bahan ajar yang dapat digunakan adalah modul.

Sesuai dengan kelebihan modul yang dikemukakan oleh Kodir modul memuat petunjuk kegiatan belajar secara mandiri (self instructional) serta memberikan kesempatan kepada siswa untuk menguji diri sendiri melalui latihan yang disajikan dalam modul. Melalui analisis siswa dijumpai bahwa peserta didik kurang aktif dalam pembelajaran, dikarenakan sumber belajar hanya berasal dari guru, sehingga menjadikan siswa belum bisa aktif dalam membangun konsep mereka sendiri.

Pada analisis tugas memuat kompetensi yang harus ditempuh oleh siswa. Kegiatan ini ditujukan untuk mengidentifikasi kemampuan yang dimiliki oleh siswa yang dikembangkan dalam pembelajaran dengan penanaman karakter tanggung jawab dan peduli lingkungan pada tema 9 subtema 3. Analisis konsep memuat materi pengembangan modul kelas 4 tema 9 subtema 3 berdasarkan nilainilai karakter tanggung jawab dan peduli lingkungan, sebagai sarana pencapaian kompetensi yang ada. Melalui kompetensi dasar yang ada, diharapkan siswa dapat mengembangkan kemampuan yang dimiliki untuk mencapai tujuan dari setiap pembelajaran dan menjadikan siswa bertanggung jawab dan peduli akan lingkungannya (Kadir, 2011).

Tahap perencanaan dimulai dengan penyusunan tes melalui pembuatan instrumen yang akan digunakan untuk mengetahui kelayakan dan keefektifan modul tematik integratif berbasis character building. Kemudian pemilihan bahan ajar yang disesuaikan dengan kebutuhan serta karakteristik peserta didik kelas 4 di SDN 03 Plaosan. Setelah itu pemilihan format agar menghasilkan modul yang menarik sehingga dapat membantu siswa di kelas IV dalam pembelajaran tematik pada tema 9 kayanya negeriku, subtema 3 pelestarian sumber daya alam di Indonesia. Selanjutnya pembuatan desain awal yaitu terdiri dari cover, kata pengantar, petunjuk penggunaan modul, daftar isi, kompetensi inti, kompetensi dasar, peta konsep pendidikan karakter, pemetaan indikator pembelajaran, materi, penugasan, umpan balik dan tindak lanjut, latihan soal, glosarium dan kunci jawaban tes formatif . 
Pada tahap pengembangan, menyusun draft modul tematik integratif berbasis character building dan disesuaikan dengan urutan desain awal modul yang diawali dengan pembuatan cover, kata pengantar, petunjuk penggunaan modul, daftar isi, kompetensi inti, kompetensi dasar, peta konsep pendidikan karakter, pemetaan indikator pembelajaran, materi, penugasan, umpan balik dan tindak lanjut, latihan soal, glosarium dan kunci jawaban tes formatif. Untuk selanjutnya modul tematik integratif berbasis character building divalidasi oleh tiga ahli yaitu ahli materi, ahli bahasa, dan ahli media dengan menggunakan kriteria kevalidan (Arikunto, 2007). Setelah produk direvisi sesuai penilaian oleh para ahli, modul tematik integratif berbasis character building diimplementasikan melalui uji coba lapangan awal atau terbatas di SDN Plaosan 3 kabupaten Malang. Modul tematik integratif berbasis character building ini dirancang untuk sistem pembelajaran secara mandiri, serta disajikan secara komunikatif dua arah dan pemberian evaluasi sebagai bahan rujukan siswa. Karakteristik modul diantaranya adalah dirancang untuk sistem pembelajaran mandiri, modul sebagai program pembelajaran yang utuh dan sistematis, modul mengandung tujuan, bahan atau kegiatan dan evaluasi, modul disajikan secara komunikatif, dua arah, modul diupayakan agar dapat mengganti beberapa peran pengajar, modul memiliki cakupan bahasa terfokus dan terukur, dan modul mementingkan aktivitas belajar pemakai. Selain itu, modul yang baik juga memiliki fungsi sebagai bahan ajar mandiri, pengganti fungsi pendidik, sebagai alat evaluasi dan sebagai bahan rujukan siswa(Prastowo, 2014).

Kevalidan modul tematik integratif berbasis character building. Modul tematik integratif berbasis character building dinilai cocok untuk pembelajaran kelas 4 pada tema 9 subtema 3, karena dapat menyediakan informasi dengan petunjuk pemakaian bagi siswa, disertai ilustrasi dan gambar yang komunikatif sehingga efektif sebagai pembelajaran dan berlatih bagi siswa. Hal ini sesuai dengan kegunaan modul dalam proses pembelajaran menurut Andriani yaitu modul sebagai penyedia informasi dasar, modul sebagai bahan instruksi atau petunjuk bagi siswa, modul sebagai bahan pelengkap dengan ilustrasi dan foto yang komunikatif serta modul bisa menjadi petunjuk mengajar yang efektif bagi pendidik dan bahan untuk berlatih siswa dalam melakukan penilaian sendiri (selfassesment) (Prastowo, 2014).

Dari validasi ahli materi dapat diketahui bahwa aspek kelayakan isi mendapat skor $89,58 \%$ yang dikategorikan "Layak", aspek kelayakan penyajian sebesar 85\% dikategorikan "Layak", aspek penilaian kontekstual sebesar 88,89\%, serta aspek penilaian character building sebesar 91,67\% yang dikategorikan "Sangat Layak". Dari 4 aspek yang berisi 37 butir pernyataan diperoleh skor keseluruhan sebesar $88,51 \%$ yang dikategorikan "Layak" yang berarti modul tematik integratif kelas 4 berbasis character building tidak perlu direvisi. Dari validasi ahli bahasa dapat diketahui bahwa skor yang didapat pada aspek kelayakan bahasa mendapat $88,89 \%$ yang dikategorikan "Layak" yang berarti modul tematik integratif kelas 4 berbasis character building tidak perlu direvisi.. Data validasi ahli media dapat diketahui bahwa skor yang didapat pada aspek kelayakan ahli media atau kegrafikaan mendapat 94,44\% yang dikategorikan "Sangat Layak" yang berarti modul tematik integratif kelas 4 berbasis character 
building tidak perlu direvisi. Dari hasil analisis tersebut menurut konversi data kuantitatif ke data kualitatif, maka modul tematik integratif berbasis character building layak diuji cobakan. Kevalidan produk ini juga dapat dilihat dari hasil penilaian praktisi atau guru(Arikunto, 2017). Validasi oleh praktisi yang sudah dianalisis oleh peneliti memperoleh skor dari aspek kelayakan isi sebesar 79,41\% yang dikategorikan "Layak" yang berarti modul tematik integratif kelas 4 berbasis character building tidak perlu direvisi. Dengan demikian dapat dipahami bahwa modul tematik integratif kelas 4 berbasis character building yang telah dibuat oleh peneliti layak untuk diujicobakan tanpa revisi. Berdasarkan hasil penilaian, modul tematik integratif kelas 4 berbasis character building telah lolos tahap validasi dengan sedikit perbaikan dan saran. Beberapa perbaikan dan saran yang dilakukan pada aspek materi maupun media menurut masukan para ahli adalah mencamtumkan nama gambar pada setiap gambar yang ada, dengan posisi penulisan sumber gambar berada setelah penulisan sumber gambar, penambahan daftar pustaka dari internet, pemberian background pada peta konsep bagian bawah, penulisan kalimat perintah dilengkapi pada setiap soal latihan atau kegiatan, perbaikan pada penulisan daftar pustaka modul, penambahan peta konsep pendidikan karakter.

Kepraktisan modul tematik integratif kelas 4 berbasis character building dapat diketahui bahwa dari indikator ketertarikan dalam kategori "sangat praktis" dengan presentase 91\%. Indikator materi dalam kategori "sangat praktis" dengan prosentase $87,5 \%$. Sedangkan indikator bahasa dalam kategori "sangat praktis" dengan prosentase 96,67\%. Maka dapat diketahui bahwa hasil uji lapangan terbatas terhadap modul tematik integratif kelas 4 berbasis character building dalam kategori“" sangat praktis" dengan rata-rata 91,72\%. Dengan demikian modul tematik integratif kelas 4 berbasis character building sangat praktis untuk digunakan sebagai pembelajaran tematik pada pada tema 9 kayanya negeriku, subtema 3 pelestarian sumber daya alam di Indonesia.

Selama uji coba berlangsung, siswa tampak antusias dan serius belajar karena pembelajaran menggunakan ilustrasi dan gambar yang menarik dalam hal tampilan dan penyajiannya. Hal ini sesuai dengan hal-hal yang harus diperhatikan dalam pembuatan bahan ajar yang membuat siswa untuk belajar mandiri dan memperoleh ketuntasan dalam proses pembelajaran sebagai berikut menurut Widodo dalam Lestari (2013) yaitu memberikan contoh-contoh dan ilustrasi yang menarik dalam rangka mendukung pemaparan materi pembelajaran, memberikan kemungkinan bagi siswa untuk memberikan umpan balik atau mengukur penguasaannya terhadap materi yang diberikan dengan memberikan soal-soal latihan, tugas, dan sejenisnya, kontekstual yang mengkaitkan suasana atau konteks tugas dan lingkungan siswa, bahasa yang digunakan cukup sederhana karena siswa hanya berhadapan dengan bahan ajar ketika belajar secara mandiri.

Berdasarkan keefektifan modul tematik integratif kelas 4 berbasis character building ini, modul tematik integratif kelas 4 berbasis character building dapat menarik perhatian siswa, membuat siswa aktif serta mempermudah siswa dalam memahami materi dan belajar secara mandiri dalam pencapaian hasil pembelajaran. Hal ini sejalan dengan pendapat Lestari (2013) bahan ajar juga berfungsi sebagai alat evaluasi pencapaian hasil pembelajaran. Bahan ajar yang 
baik sekurang-kurangnya mencakup petunjuk belajar, kompetensi yang akan dicapai, isi pelajaran, informasi pendukung, latihan-latihan, petunjuk kerja, evaluasi, dan respons terhadap hasil evaluasi.

Keefektifan modul tematik integratif kelas 4 berbasis character building ini ditunjukkan dari hasil tes kemampuan siswa pada saat peneliti melakukan uji coba, dari 10 siswa mendapat nilai diatas Kriteria Ketuntasan Minimal (KKM) dengan rata-rata nilai 83,75 . Dari hasil tersebut maka modul tematik integratif kelas 4 berbasis character building dapat dikatakan "efektif" digunakan sebagai bahan ajar dalam kegiatan pembelajaran.

Pengembangan modul tematik integratif kelas 4 berbasis character building ini layak dan praktis digunakan karena telah memenuhi kriteria kevalidan, kepraktisan dan keefektifan dengan nilai yang tinggi. Sesuai dengan penelitian yang dilakukan oleh Maryani dan Ismaniati (2015) modul yang dikembangkan layak digunakan dengan validitas modul sebesar 92,86\% menurut ahli materi; 85,45 menurut ahli media; 92,86\% menurut subjek uji coba pada uji coba lapangan terbatas; $97,40 \%$, menurut subjek uji coba pada uji coba lapangan utama, dan 93,16\% menurut subjek uji coba pada uji coba lapangan operasional. Selaijn itu, modul yang dikembangkan efektif dalam meningkatkan rerata skor pemahaman subjek uji coba yang belum mengikuti pelatihan Kurikulum 2013 sebesar 23,60.

Subjek uji coba yang sudah mengikuti pelatihan Kurikulum 2013 sebesar 21,05. Ketiga, modul yang dikembangkan efektif membantu subjek uji coba dalam mengembangkan RPP dengan rerata nilai RPP yang dikembangkan oleh subjek uji coba sebesar 79,48 yang menunjukkan bahwa modul efektif digunakan sebagai bahan belajar mandiri. Penelitian lain juga dilakukan oleh Penelitian lain juga dilakukan oleh Setyowati, Parmin, \& Widiyatmoko (2013) bahwa dari hasil penelitian dan pembahasan modul IPA berkarakter peduli lingkungan tema polusi layak digunakan oleh siswa kelas XI SMK Negeri 11 Semarang. Hal itu terbukti dengan persentase hasil validasi pakar materi 3,57, pakar karakter 3,57, dan pakar bahasa 3,53, telah mencapai kriteria penilaian yaitu layak sesuai dengan standar penilaian buku teks BSNP 2006 yang telah dimodifikasi. Selain itu, dari hasil penelitian dan pembahasan modul IPA berkarakter peduli lingkungan yang dikembangkan efektif digunakan dalam pembelajaran di SMK Negeri 11 Semarang. Hal itu terbukti dengan tanggapan positif yang diberikan guru dan siswa serta tingkat ketuntasan klasikal siswa $86 \%$ telah mencapai kriteria yaitu $\geq 85 \%$ siswa telah tuntas belajar $(\mathrm{KKM} \geq 75)$ dengan rata-rata hasil belajar siswa sebesar 80,7.

\section{KESIMPULAN DAN SARAN}

Pada penelitian ini pembuatan modul tematik integratif berbasis character building dengan pendekatan kurikulum 2013 untuk kelas 4 khususnya pada tema 9 kayanya negeriku subtema 3 pelestarian sumber daya alam di Indonesia didasarkan pada penelitian dan pengumpulan data, tahap perencanaan., pengembangan modul, dilanjutkan dengan validasi oleh para ahli dan uji coba lapangan terbatas pada 1 guru SD kelas 4 Plaosan 03 beserta 10 siswanya, dan diakhiri dengan revisi. 
Hasil penelitian modul layak digunakan, berdasarkan penilaian ahli materi memperoleh skor $88,51 \%$, ahli bahasa $88,89 \%$, ahli media $94,44 \%$ dan peer reviewer $79,41 \%$. Modul praktis digunakan dengan perolehan skor 91,72\%, dan efektif digunakan dengan perolehan skor rata-rata 83,75\%. Diharapkan untuk pengguna modul tematik-integratif berbasis character building dapat dijadikan sebagai penunjang bahan ajar.

\section{DAFTAR RUJUKAN}

Arikunto. (2017). Prosedur Penelitian (edisi revisi). jakarta: Rineka Cipta.

Arikunto, S. (2007). Prosedur Penelitian (edisi revisi). Jakarta: Rineka Cipta.

Hasyim, A. (2016). Metode Penelitian dan Pengembangan di Sekolah. yogjakarta: media akademi.

Kadir, A. (2011). Strategi Belajar Mengajar. Bandung: Pustaka Setia.

Lestari, I. (2013). Pengembangan Bahan Ajar Berbasis Kompetensi (sesuai dengan Kurikulum Tingkat Satuan Pendidikan). Padang: Akademia Permata.

M.Arifin, barnawi dan. (2012). strategi dan pembelajaran pendidikan karakter. yogyakarta: ar-ruzz media.

Maryani, M., \& Ismaniati, C. (n.d.). Pengembangan Modul Penyusunan Rpp Tematik-integratif Berbasis Character Building Sebagai Bahan Belajar Guru SD. Jurnal Pendidikan Karakter, (2).

Prastowo, A. (2014). Pengembangan Bahan Ajar Tematik Tinjauan Teoretis dan Praktik. Jakarta: Kencana Prenadamedia Group.

Sanjaya, W. (2010). kurikulum dan pembelajaran, teori dan praktek pengembangan KTSP. Jakarta: Kencana.

Setyowati, R., Parmin, P., \& Widiyatmoko, A. (2013). Pengembangan modul IPA berkarakter peduli lingkungan tema polusi sebagai bahan ajar siswa SMK N 11 Semarang. Unnes Science Education Journal, 2(2).

Sudrajat, A. (2011). Mengapa Pendidikan Karakter? Jurnal Pendidikan Karakter (Vol. 1). 